\title{
Assessment of Ground Water Quality in Baba I Village, North-West Cameroon
}

\author{
Nchofua Festus Biosengazeh ${ }^{*}$, Nelson Alakeh Mofor ${ }^{2}$, Njoyim Estella Buleng Tamungang ${ }^{1,3}$, \\ Antoine David Mvondo-Ze ${ }^{4}$
}

${ }^{1}$ Research Unit of Noxious Chemistry and Environmental Engineering (RUNOCHEE), Department of Chemistry, Faculty of Science, University of Dschang, Dschang, Cameroon

${ }^{2}$ Department of Mining and Mineral Engineering, National Higher Polytechnic Institute (NAHPI), The University of Bamenda, Bambili, Cameroon

${ }^{3}$ Department of Chemistry, Higher Teacher Training College, The University of Bamenda, Bambili, Cameroon

${ }^{4}$ Research Unit of Soil Analysis and Environmental Chemistry (RUSAEC), Department of Soil Science, Faculty of Agronomy and Agricultural Sciences (FAAS), University of Dschang, Dschang, Cameroon

Email: ^fnchofua@yahoo.com

How to cite this paper: Biosengazeh, N. F., Mofor, N. A., Tamungang, N. E. B., \& Mvondo-Ze, A. D. (2020). Assessment of Ground Water Quality in Baba I Village, North-West Cameroon. Journal of Geoscience and Environment Protection, 8, 87-104.

https://doi.org/10.4236/gep.2020.84007

Received: March 5, 2020

Accepted: April 23, 2020

Published: April 26, 2020

Copyright $\odot 2020$ by author(s) and Scientific Research Publishing Inc. This work is licensed under the Creative Commons Attribution International License (CC BY 4.0).

http://creativecommons.org/licenses/by/4.0/

\section{(c) (i) Open Access}

\begin{abstract}
This study investigated the quality of ground water in Baba I, North-West Cameroon, in order to determine its suitability for domestic uses following World Health Organisation (WHO) guidelines. Inhabitants of this locality consume water from these sources without any prior treatment which can lead to health problems if the water sources are contaminated. Six water sources were sampled in November 2017, January, April and July 2018 and examined for organoleptic, physico-chemical and bacteriological parameters using standard methods. Results of organoleptic and physical parameters showed that most of the sources were within the WHO acceptable limits with $\mathrm{pH}$ varying from moderately acidic to weakly basic. Chemical properties revealed that all the analysed ions were found within the WHO guidelines and the water sources ranged from soft (hardness $<60 \mathrm{mg} / \mathrm{L})$ to moderately hard $(60 \mathrm{mg} / \mathrm{L} \leq$ hardness $\leq 120 \mathrm{mg} / \mathrm{l})$, with iron slightly exceeding the WHO guideline value of $0.3 \mathrm{mg} / \mathrm{L}$ in the well of Kwebessi (Wkw) in November 2017 and July 2018. Piper's trilinear diagrams showed that the analysed waters were calcium and magnesium bicarbonate type. Small to average seasonal influences were observed in the variations of temperature and the concentrations of $\mathrm{Na}^{+}, \mathrm{K}^{+}, \mathrm{Ca}^{2+}, \mathrm{Mg}^{2+}, \mathrm{NO}_{3}^{-}$, and $\mathrm{NH}_{4}^{+}(p<0.05)$. Faecal coliforms and specific bacteria namely: Escherichia coli, Enterobacter, Streptococcus, Salmonella and Shigella spp, were identified in all the sampled waters, suggesting recent contamination of the sources by human or animal faeces. The sources were unfit for domestic uses and thus, exposed the local population to water borne diseases such as typhoid, diarrhoea and dysentery. Hence, home treatment methods such as chlorination, filtration, boiling and solar disinfection should be implemented prior to consumption.
\end{abstract}




\section{Keywords}

Ground Water, Water Sources, Physico-Chemical Properties, Faecal Coliforms, Water Borne Diseases

\section{Introduction}

Safe and affordable supply of potable water is a basic human need. The quality of water has a great impact on public health. Poor microbiological quality of water is likely to lead to the outbreak of infectious water borne diseases. Chemical water quality is generally not an immediate call for concern as its impact on health tends to be chronic long-term effects. However, acute effects may be encountered where major pollution has occurred or where levels of certain chemicals are high from natural sources, such as fluorides, or anthropogenic sources, such as nitrates (WHO, 2009). Although access to safe and reliable water supplies has received increased attention from governments around the world in recent years, 663 million people with 319 million in Sub-Sahara Africa, of which 80\% live in rural areas, still lack improved drinking water sources and 2.5 billion people are without access to an improved sanitation facility (WHO \& UNICEF, 2015; Njoyim et al., 2016a).

Cameroon is one of the sub-Sahara African Countries where access to potable water and sanitation is still a burden to the population especially in rural areas. Despite the fact that Cameroon is blessed with many available water resources estimated to be 322 billion cubic meters with an annual available water per inhabitant of 21,000 $\mathrm{m}^{3}$ (Ako Ako et al., 2010), access to suitable water for domestic purposes is still a major public health concern as water related diseases represent about two-thirds of all the diseases in this country and are responsible for approximately $50 \%$ of death cases recorded annually (Katte et al., 2003; Wirmvem et al., 2013a). In spite of all government efforts through partnerships with Non-Governmental Organisations and the African Development Bank, Cameroon's Millennium Development Goals (MDGs) for rural water and sanitation failed, as only $44.6 \%$ and $28.8 \%$ of the rural population had access to improved water and sanitation facilities in 2015 against the targets of $80 \%$ and 60\% respectively (INS, 2015).

Baba I is a rural community, found in Babessi sub-division, North-West Cameroon. In this community, pipe borne water is not functional and the population relies mainly on groundwater sources (wells, springs and manual pump boreholes) with little available information on their physico-chemical and bacteriological properties. They judge the suitability of water from any source for domestic purposes based on its appearance and odour and the water is used without any prior treatment. As noticed on the field, most of the wells are shallow and not properly protected, thus exposed to contamination. The springs are not properly taken care of as they are exposed to dust, close to farms, often shared with animals and are exposed to floods in the rainy season, suggesting their contamination by faeces and fertilizers. The boreholes are mostly used for laundry, bathing and cooking but not for drinking due to their unpleasant taste as reported by the 
users. Suitability of water from these sources for domestic purposes is thus questionable and there arises the need for proper quality assessment and monitoring as the population maybe exposed to water borne diseases. The main objective of this study was thus, to examine the quality of groundwater in Baba I in order to ascertain its suitability for domestic uses following WHO standards. To achieve this objective, water samples were analysed for organoleptic, physico-chemical and bacteriological properties and recommendations were made based on the findings obtained.

\section{Materials and Methods}

\subsection{Description of Sampling Site}

Baba I village (Papiakum) is one of the four villages that make up Babessi sub division and one of the thirteen villages of Ngoketunjia division in the North West region of Cameroon (Figure 1). It is located along the National road number 7, some $50 \mathrm{~km}$ away from Bamenda town. Baba I lies between latitude $6^{\circ} 3^{\prime} 44^{\prime \prime}$ North and longitude $10^{\circ} 29^{\prime} 25^{\prime \prime}$ East with an elevation of $1138 \mathrm{~m}$ above sea level. The village has both lowlands and an upper mountainous area with an estimated population of 40,000 inhabitants. Five gravity-powered catchments supply the village with water; but, for over seven years, the distribution has not been working in the whole village. In the upper part of the village, water sometimes flows through connected taps, while the lower village is completely cut off (CAMAAY, 2015). The main activities of the inhabitants are agriculture, breeding and small scale trading. The climate is characterized by a short dry season from November to February and a long raining season from March to October. The annual maximum temperature varies between $27.2^{\circ} \mathrm{C}$ and $33.6^{\circ} \mathrm{C}$ whereas the annual minimal temperature varies between $7.8^{\circ} \mathrm{C}$ and $15.9^{\circ} \mathrm{C}$. Pluviometry varies between $1270 \mathrm{~mm}$ and $1778 \mathrm{~mm}$ of water per year. Its hydrology is characterized by the existence of small rivers, streams, springs and swamps. The ground is mainly basaltic, trachytic and/or granitic, thus favourable for agriculture and pasture. The vegetation is mainly savannah type with short stunted trees (CVUC, 2019).

\subsection{Sampling and Preservation}

Water samples were collected from six sources in November 2017, January, April and July 2018. At each sampling point, three samples were collected in clean and labelled polyethylene containers of $500 \mathrm{~mL}$ capacity each. The containers and caps were thoroughly rinsed with water to be sampled before collection. The collections were done very early in the morning before sunrise and the samples packaged in a cooler containing ice in order to maintain the temperature at $4^{\circ} \mathrm{C}$ (Rodier et al., 2009). Finally, the samples were transported to the Research Unit of Animal Physiology and Microbiology and the Research Unit of Soil Analysis and Environmental Chemistry of the University of Dschang for preservation and analyses. A global positioning system (G.P.S.), (Garmin Etrex Vista) was used to locate the study site. The source type, sample code and geographical coordinates are presented in Table 1 . 


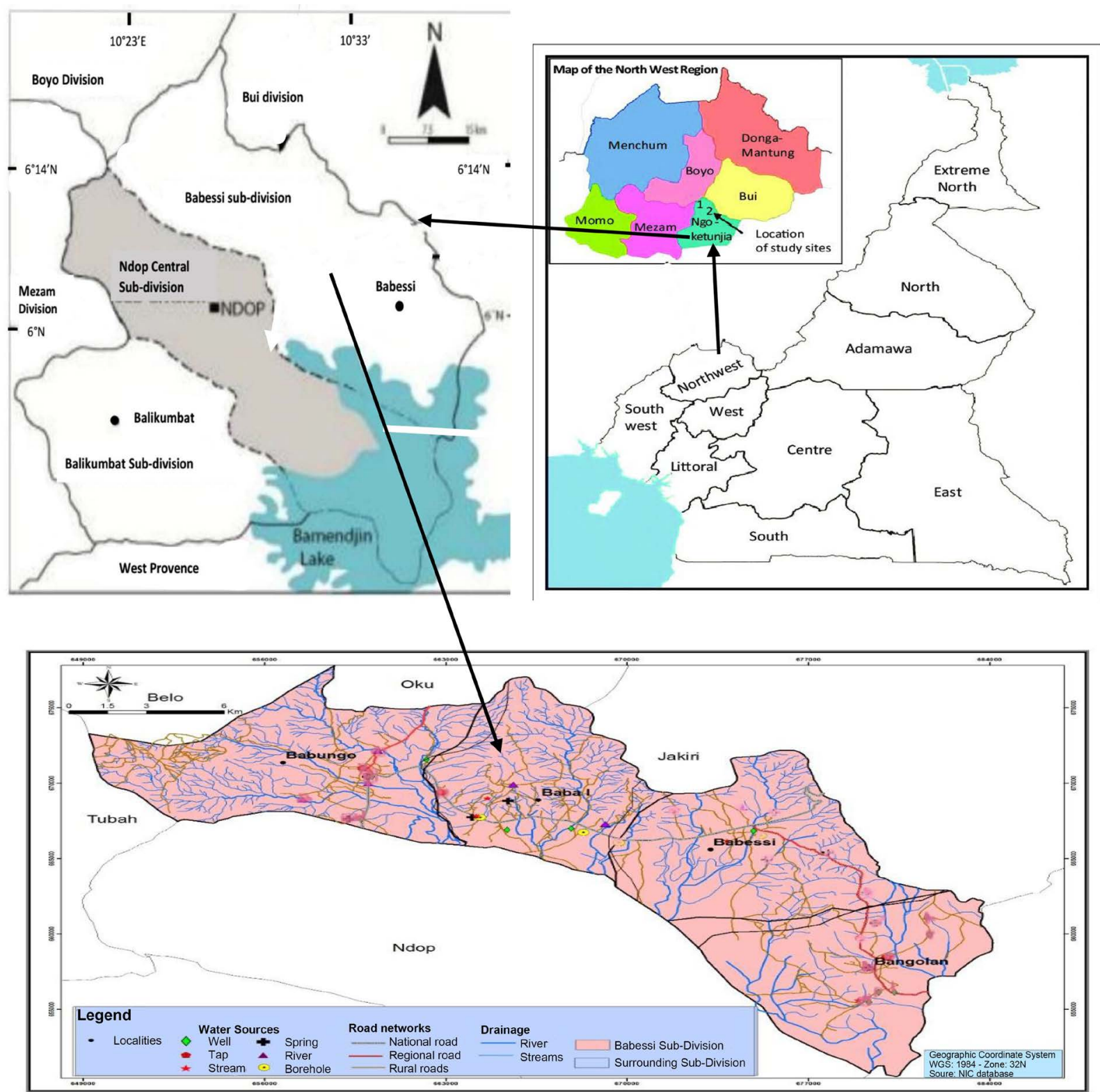

Figure 1. Map of the study area: map of Cameroon, indicating the map of North west region, map of North west region indicating the map of Ngo-ketunjia, map of Ngo-ketunjia indicating the map of Baba I in Babessi subdivision showing the sampling points.

Table 1. Source type, sample code and geographical coordinates.

\begin{tabular}{|c|c|c|c|c|}
\hline Quarter & Source type & Sample code & GPS coordinates & Elevation $(\mathrm{m})$ \\
\hline Mechacha & Spring & Sme & N06 $02^{\prime} 20.2^{\prime \prime}$ E010 $28^{\prime} 54.9^{\prime \prime}$ & 1138 \\
\hline Mecheche & Borehole & Bme & N06 $02^{\prime} 19.9^{\prime \prime}$ E010 $29^{\prime} 05.4^{\prime \prime}$ & 1172 \\
\hline Kwebessi & Borehole & Bkw & N0601'47.3" E010³1'14.9" & 1185 \\
\hline Kwebessi & Well & Wkw & N0601'55.5" E010³0'59.4" & 1172 \\
\hline Meya & Spring & Smy & N06 $02^{\prime} 55.2^{\prime \prime}$ E010 $29^{\prime} 40.7^{\prime \prime}$ & 1232 \\
\hline Koyart & Well & Wko & N06 $01^{\prime} 53.0^{\prime \prime}$ E010²9'38.9" & 1176 \\
\hline
\end{tabular}




\subsection{Laboratory Analyses}

\subsubsection{Organoleptic and Physicochemical Analyses}

The water samples were observed with naked eyes for gross appearance and examined for offensive odour through subjective organoleptic assessment.

Temperature (T), pH, Electrical Conductivity (EC), and Total Dissolved Solids (TDS) were measured in-situ with the help of a calibrated multimeter (HANNAH198128). Turbidity was measured using a turbidimeter (Model DRT, 100B, MF scientific, Inc) by measuring the propagation of light projected towards the tube containing the sample. Chloride content was determined by titrating $25 \mathrm{~mL}$ of each water sample with silver nitrate using potassium chromate indicator. Nitrate and ammonium were determined by Kjeldahl's distillation method: $25 \mathrm{~mL}$ of each sample was pipetted and placed into a distillation tube in which two drops of phenolphthalein and a small quantity of $\mathrm{MgO}$ were added and a pink colour was observed. The tube was then distilled and the vapour of $\mathrm{NH}_{3}$ resulting from the alkalinisation of $\mathrm{NH}_{4}^{+}$by $\mathrm{MgO}$ was trapped by $100 \mathrm{~mL}$ boric acid contained in a $250 \mathrm{~mL}$ conical flask. The distillate was finally titrated under permanent stirring with $0.01 \mathrm{~N}$ sulfuric acid and the end point was marked by a persisting red colour. The distillation tube was removed and alllowed to cool. Devarda alloy was then added to the solution and another distillation was proceeded during which nitrate ions reduced by Devarda alloy were trapped by $100 \mathrm{~mL}$ of boric acid contained in a $250 \mathrm{~mL}$ conical flask. The distillate was once again titrated under permanent stirring with $0.01 \mathrm{~N}$ sulfuric acid. Phosphates were determined by UV visible spectrophotometric analysis: calibration curve was established using 0,25 , 50 and 100 ppm phosphate solutions. $10 \mathrm{~mL}$ boric acid, $2 \mathrm{~mL}$ sulfomolybdic mixture and $4 \mathrm{~mL}$ ascorbic acid were added to $2 \mathrm{~mL}$ of each sample. The mixtures were homogenised and allowed for 30 minutes for colour to develop. Finally, readings were done using a UV visible spectrophotometer at a wavelength of $700 \mathrm{~nm}$. Bicarbonates were determined by acid-base titration with $\mathrm{HCl}$ using phenolphthalein and dilute methyl orange indicators. Sulphates were determined by gravimetric analysis. $\mathrm{Na}^{+}$and $\mathrm{K}^{+}$were determined by flame photometry while $\mathrm{Ca}^{2+}$ and $\mathrm{Mg}^{2+}$ were determined by complexometric titration with EDTA. Iron was determined by colorimetry.

\subsubsection{Bacteriological Analyses}

\section{1) Multiple tube fermentation technique}

$100 \mathrm{~mL}$ water sample was distributed $(1 \mathrm{~mL}$ amount, $10 \mathrm{~mL}$ amount, and 50 $\mathrm{mL}$ amount) in bottles of sterile selective culture broth containing lactose and an indicator. After incubation, the number of bottles in which lactose fermentation with acid and gas production occurred was counted. Lactose is fermented by coliforms present in the water. With reference to probability tables, the most probable number of coliforms in the $100 \mathrm{~mL}$ water sample was estimated and the water category obtained.

\section{2) Count plate technique}

Culture media for the specific bacteria were prepared and introduced into petri 
dishes containing $1 \mathrm{~mL}$ each of water sample and mixed until solidification. The petri dishes were then incubated at $44^{\circ} \mathrm{C}$ for 24 hours after which colonies of bacteria were counted.

\subsection{Water Quality Index}

The water quality index (WQI) model simplifies the presentation of results of an analysis related to a water body as it summarises in one value a series of parameters analysed. WQI also eases comparison between different sampling sites and events (Tyagi et al., 2014; Mofor et al., 2017; Satish Chandra, 2017). In this study, sixteen important parameters were chosen for the calculation of water quality index. WQI was calculated using the weighted Arithmetic Index Method (Mofor et al., 2017; Satish Chandra, 2017). WQI values and the status of water quality are presented in Table 2 . The following steps were used for determining the WQI. In the first step, the unit weight $\left(W_{i}\right)$ for each water quality parameter was determined using the following formula:

$$
W_{i}=\frac{K}{S_{i}}
$$

where $S_{i}$ is standard value of $I^{\text {th }}$ parameter recommended by WHO; $K$ is the proportionality constant which is calculated by using the following formula:

$$
K=\frac{1}{\sum_{i=1}^{n}\left(\frac{1}{S_{i}}\right)}
$$

The inverse of the sum of inverses of standard parameters is used in order to make parameters expressed by large numbers to weigh less in the final formula (Equation (4)). In the second step, quality rating or sub index $\left(q_{i}\right)$ was computed for each of the parameters using the expression:

$$
q_{i}=\frac{V_{i}-V_{o}}{S_{i}-V_{o}} \times 100
$$

where $V_{i}$ is estimated value of $I^{\text {th }}$ parameter in the analysed water sample; $V_{0}$ is ideal value of this parameter in pure water (it is zero for all parameters except $\mathrm{pH}=7.0$ and TDO $=14.6 \mathrm{mg} / \mathrm{L}) ; S_{i}$ is recommended standard value of $I^{\text {th }}$ parameter given by $\mathrm{WHO}$.

Table 2. Water Quality Index (WQI) and Status of water quality (Mofor et al., 2017; Satish Chandra, 2017).

\begin{tabular}{ccc}
\hline WQI & Water Quality Status & Grade \\
\hline $0-25$ & Excellent & A \\
$26-50$ & Good & B \\
$51-75$ & Poor & C \\
$76-100$ & Very poor & D \\
$>100$ & Unsuitable for drinking & E \\
\hline
\end{tabular}


In the final step, the overall WQI was calculated by using following formula:

$$
q_{i}=\frac{\sum_{i=1}^{n} q_{i} W_{i}}{\sum_{i=1}^{n} W_{i}}
$$

Reference WQI table (Table 2) is used to deduce the sample's status.

\subsection{Statistical Analyses}

A one-way between groups Analysis of Variance (ANOVA) was used to explore seasonal impact on water quality at $95 \%$ confidence interval. Post-hoc comparisons were also performed using the Tukey HSD test and Pearson correlation was used to verify relationships between water parameters. The effect size was calculated using the following formula:

$$
\text { eta squared }=\frac{\text { sum of squares between groups }}{\text { total sum of squares }}
$$

Analyses were performed with the help of Statistical Package for Social Sciences (SPSS) version 20.0.

Piper trilinear diagrams were drawn using chemical properties to classify the selected ground water sources in to various hydro-chemical facies.

\section{Results and Discussion}

\subsection{Results}

Results of organoleptic parameters presented in Table 3 showed that all the water sources were clean and clear except the well in kwebessi (Wkw) which was not clear with tiny brownish debris and had rotten leaves odour.

\begin{tabular}{|c|c|c|c|c|c|c|c|c|}
\hline \multirow{3}{*}{$\begin{array}{c}\text { Parameters } \\
\text { Month }\end{array}$} & \multicolumn{4}{|c|}{ Appearance } & \multicolumn{4}{|c|}{ Odour } \\
\hline & Nov & Jan & Apr & Jul & Nov & Jan & Apr & Jul \\
\hline & 17 & 18 & 18 & 18 & 17 & 18 & 18 & 18 \\
\hline Sme & Clear and clean & Clear and clean & Clear and clean & Clear and clean & Odourless & Odourless & Odourless & Odourless \\
\hline Bme & Clear and clean & Clear and clean & Clear and clean & Clear and clean & Odourless & Odourless & Odourless & Odourless \\
\hline $\mathrm{Bkw}$ & Clear and clean & Clear and clean & Clear and clean & Clear and clean & Odourless & Odourless & Odourless & Odourless \\
\hline Wkw & $\begin{array}{l}\text { Not clear with tiny } \\
\text { brownish debris }\end{array}$ & $\begin{array}{l}\text { Not clear with tiny } \\
\text { brownish debris }\end{array}$ & $\begin{array}{l}\text { Not clear with tiny } \\
\text { brownish debris }\end{array}$ & Clear and clean & $\begin{array}{c}\text { Rotten leaves } \\
\text { odour }\end{array}$ & $\begin{array}{c}\text { Rotten leaves } \\
\text { odour }\end{array}$ & $\begin{array}{c}\text { Rotten leaves } \\
\text { odour }\end{array}$ & $\begin{array}{c}\text { Rotten leaves } \\
\text { odour }\end{array}$ \\
\hline Smy & Clear and clean & Clear and clean & Clear and clean & Clear and clean & Odourless & Odourless & Odourless & Odourless \\
\hline Wko & Clear and clean & Clear and clean & Clear and clean & Clear and clean & Odourless & Odourless & Odourless & Odourless \\
\hline WHO & \multicolumn{4}{|c|}{ Clean and clear } & \multicolumn{4}{|c|}{ Odourless } \\
\hline
\end{tabular}

Table 3. Results of organoleptic parameters.

Nov17: November 2017; Jan18: January 2018; Apr18: April 2018; Jul18: July 2018. 
Results of physical parameters are presented in Table 4. Temperature ranged between $17.2^{\circ} \mathrm{C}$ and $22.3^{\circ} \mathrm{C}$ with a maximum mean value of $(20.2 \pm 0.7)^{\circ} \mathrm{C} \mathrm{ob}$ tained in July 2018. $\mathrm{pH}$ ranged from 5.6 to 8.1 with a maximum average value of $(7.2 \pm 0.6)$. All the water sources had low Electrical Conductivity(EC) and Total Dissolved Solids (TDS) ranging from 22.0 to $95.2 \mu \mathrm{S} / \mathrm{cm}$ and from 16.5 to 67.6 $\mathrm{mg} / \mathrm{L}$ with maximum means of $(54.4 \pm 25.4) \mu \mathrm{S} / \mathrm{cm}$, and $(34.9 \pm 16.5) \mathrm{mg} / \mathrm{L}$ respectively. Turbidity fell in the range 0.5 - 3.6 NTU with a maximum mean value of $(2.1 \pm 1.1)$ NTU in July 2018 .

Results of chemical parameters analysed are presented in Table 5 and Table 6. The ions analysed included major water minerals, ammonium, phosphates and Iron. Calcium and magnesium concentrations were below the WHO guideline values of $75 \mathrm{mg} / \mathrm{L}$ and $30 \mathrm{mg} / \mathrm{L}$ with maximum mean values of $(39.67 \pm 17.10) \mathrm{mg} / \mathrm{L}$ and $(12.10 \pm 2.53) \mathrm{mg} / \mathrm{L}$ respectively in July $2018 . \mathrm{Na}^{+}, \mathrm{K}^{+}, \mathrm{Cl}^{-}, \mathrm{HCO}_{3}^{-}, \mathrm{SO}_{4}^{2-}, \mathrm{NO}_{3}^{-}$, $\mathrm{NH}_{4}^{+}$and $\mathrm{PO}_{4}^{3-}$ were all found in low concentrations and ranged from 0.24 to $6.15 \mathrm{mg} / \mathrm{L}, 0.22$ to $12.98 \mathrm{mg} / \mathrm{L}, 0.04$ to $0.80 \mathrm{mg} / \mathrm{L}, 14.20$ to $67.10 \mathrm{mg} / \mathrm{L}, 0.10$ to $7.28 \mathrm{mg} / \mathrm{L}, 0.18$ to $5.34 \mathrm{mg} / \mathrm{L}, 0.11$ to $10.92 \mathrm{mg} / \mathrm{L}, 1.67$ to $5.34 \mathrm{mg} / \mathrm{L}$ and 0.00 to $4.03 \mathrm{mg} / \mathrm{L}$ with maximum mean values of $(2.26 \pm 2.06) \mathrm{mg} / \mathrm{L},(8.48 \pm 3.47) \mathrm{mg} / \mathrm{L}$,

Table 4. Results of physical parameters.

\begin{tabular}{|c|c|c|c|c|c|c|c|c|c|c|c|c|c|c|c|c|c|c|c|c|}
\hline \multirow{3}{*}{$\begin{array}{c}\text { Parameters } \\
\text { Month }\end{array}$} & \multicolumn{4}{|c|}{$\mathrm{T}\left({ }^{\circ} \mathrm{C}\right)$} & \multicolumn{4}{|c|}{$\mathrm{pH}$} & \multicolumn{4}{|c|}{$\mathrm{EC}(\mu \mathrm{S} / \mathrm{cm})$} & \multicolumn{4}{|c|}{ TDS (mg/L) } & \multicolumn{4}{|c|}{ Tur (NTU) } \\
\hline & Nov & Jan & Apr & Jul & Nov & Jan & Apr & Jul & Nov & Jan & Apr & Jul & Nov & Jan & Apr & Jul & Nov & Jan & Apr & Jul \\
\hline & 17 & 18 & 18 & 18 & 17 & 18 & 18 & 18 & 17 & 18 & 18 & 18 & 17 & 18 & 18 & 18 & 17 & 18 & 18 & 18 \\
\hline Sme & 19.8 & 17.2 & 18.1 & 20.4 & 7.3 & 6.2 & 7.8 & 6.9 & 43.5 & 64.1 & 53.2 & 51.7 & 37.2 & 43.4 & 36.0 & 36.8 & 0.7 & 0.5 & 0.4 & 0.65 \\
\hline Bme & 20.2 & 19.7 & 20.1 & 19.3 & 6.7 & 6.8 & 6.0 & 7.5 & 87.2 & 95.1 & 75.0 & 95.2 & 51.1 & 63.8 & 49.3 & 67.6 & 2.3 & 0.75 & 1.2 & 2.1 \\
\hline Bkw & 21.1 & 18.0 & 21.2 & 20.4 & 6.3 & 7.6 & 5.9 & 6.9 & 52.3 & 65.1 & 45.5 & 42.2 & 36.5 & 31.1 & 29.1 & 29.4 & 0.7 & 0.6 & 0.7 & 1.2 \\
\hline Wkw & 21.0 & 19.0 & 22.3 & 21.1 & 7.3 & 7.7 & 6.6 & 6.3 & 28.8 & 36.6 & 22.0 & 23.0 & 20.3 & 24.6 & 17.2 & 16.5 & 3.6 & 1.9 & 2.8 & 3.5 \\
\hline Smy & 19.0 & 17.2 & 17.3 & 19.6 & 8.1 & 7.3 & 6.8 & 8.0 & 39.3 & 25.4 & 35.0 & 32.1 & 25.0 & 18.2 & 24.2 & 23.0 & 0.5 & 0.6 & 1.2 & 3.0 \\
\hline Wko & 19.5 & 18.5 & 19.8 & 20.5 & 7.5 & 6.4 & 5.6 & 6.2 & 37.3 & 40.3 & 39.8 & 40.5 & 32.1 & 28.0 & 25.1 & 35.6 & 1.2 & 1.5 & 1.1 & 2.3 \\
\hline WHO & \multicolumn{4}{|c|}{$15-25$} & \multicolumn{4}{|c|}{$6.5-8.5$} & \multicolumn{4}{|c|}{2000} & \multicolumn{4}{|c|}{600} & \multicolumn{4}{|c|}{$1-5$} \\
\hline
\end{tabular}

T: Temperature; pH: Hydrogen potential; EC: Electrical Conductivity; Tur: Turbidity.

Table 5. Results of the analysed cations.

\begin{tabular}{|c|c|c|c|c|c|c|c|c|c|c|c|c|c|c|c|c|c|c|c|c|c|c|c|c|}
\hline \multirow{3}{*}{$\begin{array}{c}\text { Parameters } \\
\text { Month }\end{array}$} & \multicolumn{4}{|c|}{$\mathrm{Na}^{+}(\mathrm{mg} / \mathrm{L})$} & \multicolumn{4}{|c|}{$\mathrm{K}^{+}(\mathrm{mg} / \mathrm{L})$} & \multicolumn{4}{|c|}{$\mathrm{Ca}^{2+}(\mathrm{mg} / \mathrm{L})$} & \multicolumn{4}{|c|}{$\mathrm{Mg}^{2+}(\mathrm{mg} / \mathrm{L})$} & \multicolumn{4}{|c|}{$\mathrm{NH}_{4}^{+} \quad(\mathrm{mg} / \mathrm{L})$} & \multicolumn{4}{|c|}{$\mathrm{Fe}^{2+}(\mathrm{mg} / \mathrm{L})$} \\
\hline & Nov & Jan & Apr & Jul & Nov & Jan & Apr & Jul & Nov & Jan & Apr & Jul & Nov & Jan & Apr & Jul & Nov & Jan & Apr & Jul & Nov & Jan & Apr & Jul \\
\hline & 17 & 18 & 18 & 18 & 17 & 18 & 18 & 18 & 17 & 18 & 18 & 18 & 17 & 18 & 18 & 18 & 17 & 18 & 18 & 18 & 17 & 18 & 18 & 18 \\
\hline Sme & 0.71 & 0.43 & 0.53 & 1.02 & 1.70 & 0.26 & 2.75 & 5.65 & 27 & 5.80 & 10 & 24 & 12.50 & 3.57 & 9.60 & 16 & 1.30 & 0.84 & 1.32 & 5.34 & 0.01 & 0.06 & 0.10 & 0.02 \\
\hline Bme & 1.20 & 0.61 & 0.24 & 1.75 & 1.42 & 0.22 & 1.44 & 2.63 & 38 & 4.50 & 31 & 68 & 14.20 & 1.81 & 7.80 & 11 & 1.70 & 0.22 & 0.92 & 2.68 & 0.20 & 0.31 & 0.15 & 0.03 \\
\hline $\mathrm{Bkw}$ & 0.74 & 0.63 & 0.32 & 6.15 & 1.54 & 0.51 & 1.04 & 12.98 & 48 & 8.60 & 32 & 56 & 13 & 5.52 & 9.70 & 10.06 & 0.84 & 0.28 & 1.08 & 2.04 & 0.01 & 0.00 & 0.06 & 0.15 \\
\hline Wkw & 0.63 & 0.71 & 1.07 & 0.98 & 1.23 & 0.60 & 1.03 & 7.76 & 29 & 3.90 & 6.80 & 34 & 4.90 & 0.11 & 2.34 & 11 & 0.57 & 0.84 & 0.92 & 1.67 & 0.36 & 0.00 & 0.02 & 0.42 \\
\hline Smy & 0.62 & 0.52 & 0.43 & 2.91 & 2.10 & 0.75 & 2.30 & 11.09 & 32 & 7.80 & 14 & 28 & 11.50 & 2.71 & 13.6 & 14.50 & 1.35 & 0.25 & 0.24 & 1.84 & 0.00 & 0.00 & 0.00 & 0.01 \\
\hline Wko & 0.40 & 0.24 & 0.34 & 0.76 & 1.10 & 0.81 & 1.03 & 10.74 & 27 & 6.70 & 10 & 28 & 6.10 & 0.32 & 4.70 & 10.01 & 1.03 & 0.18 & 1.12 & 4.56 & 0.01 & 0.00 & 0.21 & 0.19 \\
\hline WHO & \multicolumn{4}{|c|}{200} & \multicolumn{4}{|c|}{200} & \multicolumn{4}{|c|}{75} & \multicolumn{4}{|c|}{30} & \multicolumn{4}{|c|}{30} & \multicolumn{4}{|c|}{0.3} \\
\hline
\end{tabular}


Table 6. Results of the analysed anions.

\begin{tabular}{|c|c|c|c|c|c|c|c|c|c|c|c|c|c|c|c|c|c|c|c|c|}
\hline \multirow{3}{*}{$\begin{array}{c}\text { Parameters } \\
\text { Month }\end{array}$} & \multicolumn{4}{|c|}{$\mathrm{HCO}_{3}^{-}(\mathrm{mg} / \mathrm{L})$} & \multicolumn{4}{|c|}{$\mathrm{SO}_{4}^{2-} \quad(\mathrm{mg} / \mathrm{L})$} & \multicolumn{4}{|c|}{$\mathrm{NO}_{3}^{-}(\mathrm{mg} / \mathrm{L})$} & \multicolumn{4}{|c|}{$\mathrm{Cl}^{-}(\mathrm{mg} / \mathrm{L})$} & \multicolumn{4}{|c|}{$\mathrm{PO}_{4}^{3-} \quad(\mathrm{mg} / \mathrm{L})$} \\
\hline & Nov & Jan & Apr & Jul & Nov & Jan & Apr & Jul & Nov & Jan & Apr & Jul & Nov & Jan & Apr & Jul & Nov & Jan & Apr & Jul \\
\hline & 17 & 18 & 18 & 18 & 17 & 18 & 18 & 18 & 17 & 18 & 18 & 18 & 17 & 18 & 18 & 18 & 17 & 18 & 18 & 18 \\
\hline Sme & 24.70 & 26.10 & 18.16 & 32.00 & 0.67 & 0.24 & 0.44 & 2.40 & 1.68 & 0.18 & 0.64 & 3.21 & 0.06 & 0.04 & 0.06 & 0.18 & 0.00 & 0.00 & 0.10 & 1.02 \\
\hline Bme & 40.10 & 34.30 & 24.40 & 56.30 & 0.36 & 0.10 & 0.15 & 7.28 & 1.12 & 0.12 & 0.91 & 5.70 & 0.70 & 0.10 & 0.70 & 0.32 & 0.01 & 0.00 & 0.00 & 0.20 \\
\hline Bkw & 35.70 & 45.60 & 58.56 & 68.02 & 0.75 & 0.34 & 0.53 & 1.25 & 1.32 & 0.56 & 2.28 & 1.03 & 0.76 & 0.26 & 0.76 & 0.80 & 0.06 & 0.00 & 0.00 & 0.09 \\
\hline Wkw & 38.98 & 27.60 & 67.10 & 49.45 & 0.44 & 0.24 & 0.42 & 0.87 & 1.62 & 0.18 & 1.96 & 7.71 & 0.36 & 0.32 & 0.36 & 0.25 & 0.20 & 0.00 & 0.00 & 0.60 \\
\hline Smy & 19.94 & 14.20 & 33.20 & 98.88 & 0.31 & 0.20 & 0.14 & 0.77 & 1.02 & 0.11 & 1.48 & 10.92 & 0.71 & 0.15 & 0.51 & 0.65 & 0.19 & 0.00 & 0.00 & 4.03 \\
\hline Wko & 15.18 & 33.18 & 28.56 & 77.92 & 0.27 & 0.30 & 0.19 & 0.74 & 1.45 & 0.11 & 0.62 & 1.56 & 0.05 & 0.15 & 0.35 & 0.09 & 0.10 & 0.08 & 0.00 & 0.77 \\
\hline WHO & \multicolumn{4}{|c|}{1000} & \multicolumn{4}{|c|}{250} & \multicolumn{4}{|c|}{50} & \multicolumn{4}{|c|}{250} & \multicolumn{4}{|c|}{$\leq 5$} \\
\hline
\end{tabular}

$(0.44 \pm 0.33) \mathrm{mg} / \mathrm{L},(38.33 \pm 19.80) \mathrm{mg} / \mathrm{L},(2.22 \pm 2.56) \mathrm{mg} / \mathrm{L},(5.02 \pm 3.84) \mathrm{mg} / \mathrm{L}$, $(3.02 \pm 1.55) \mathrm{mg} / \mathrm{L}$ and $(1.12 \pm 1.47) \mathrm{mg} / \mathrm{L}$ respectively. Iron ranged from 0.00 to $0.36 \mathrm{mg} / \mathrm{L}$ and had a maximum mean value of $(0.98 \pm 0.15) \mathrm{mg} / \mathrm{L}$.

Results of water quality index (WQI) for the analysed ground water samples are presented in Table 7. The combined effect of physical and chemical parameters gave water quality indices ranging between 1.79 and 124.61 with Wkw recording the highest WQI value in July.

Results of bacteriological analysis are presented in Table 8 and Figure 2. Faecal coliforms were found in all the water samples with Most Probable Number ranging from 08 to $100 / 100 \mathrm{~mL}$. Based on WHO classification, Sme in all the sampling sessions and Smy in November were acceptable for human consumption (category B) while the remaining sources were either of high risk for consumption (category C) or grossly polluted (Category D). Detailed investigations of the water samples also revealed the presence of specific bacteria in decreasing order of abundance as follows: Enterobacter spp, Escherichia coli spp, Streptococcus spp, Salmonella spp and Shigella spp (Figure 2), with colony count ranging from 15 to $350 \mathrm{CFU} / \mathrm{mL}, 10$ to $300 \mathrm{CFU} / \mathrm{mL}, 15$ to $250 \mathrm{CFU} / \mathrm{mL}, 00$ to $150 \mathrm{CFU} / \mathrm{mL}$ and 00 to $157 \mathrm{CFU} / \mathrm{mL}$ respectively.

Results of One-way between groups ANOVA that was applied on the analysed water parameters are presented in Table 9.

\subsection{Discussion}

\subsubsection{Organoleptic and Physical Parameters}

Organoleptic parameters examined include appearance and odour. Based on observations, all the water sources were clean and clear except the well in kwebessi (Wkw) which was not clear with tiny brownish debris and had the odour of rotten leaves. The good organoleptic properties of most of these sources could be justified by the fact that these are ground waters which are naturally filtered as they flow vertically from underground. A similar observation was made by Mofor et al. (2017) while assessing the quality of some springs in the Awing community, North West Cameroon. Odour in Wkw was surely caused by the decomposition of leaves 
N. F. Biosengazeh et al.

Table 7. Water quality index values, water quality status and grades.

\begin{tabular}{|c|c|c|c|c|c|c|c|c|}
\hline \multirow{3}{*}{ Sample code } & \multicolumn{4}{|c|}{ WQI } & \multicolumn{4}{|c|}{ Water quality (grade) } \\
\hline & Nov & Jan & Apr & Jul & Nov & Jan & Apr & Jul \\
\hline & 17 & 18 & 18 & 18 & 17 & 18 & 18 & 18 \\
\hline Sme & 8.87 & 13.92 & 36.13 & 10.49 & Excellent (A) & Excellent (A) & Excellent (A) & Excellent (A) \\
\hline Bme & 62.22 & 88.56 & 39.70 & 19.66 & Poor (C) & Very poor (D) & Good (B) & Good (B) \\
\hline Bkw & 2.34 & 7.44 & 12.94 & 46.69 & Excellent (A) & Excellent (A) & Excellent (A) & Good (B) \\
\hline Wkw & 114.16 & 10.64 & 12.27 & 124.61 & Unfit for drinking (E) & Excellent (A) & Excellent (A) & Unfit for drinking $(\mathrm{E})$ \\
\hline Smy & 10.68 & 5.34 & 3.53 & 24.17 & Excellent (A) & Excellent (A) & Excellent (A) & Excellent (A) \\
\hline Wko & 11.48 & 1.79 & 53.84 & 56.80 & Excellent (A) & Excellent (A) & Poor (C) & Poor (C) \\
\hline
\end{tabular}

Table 8. Most probable Number (MPN) of coliforms in $100 \mathrm{~mL}$ of water.

\begin{tabular}{ccccccccc}
\hline Parameters & \multicolumn{9}{c}{ Most probable Number (MPN) of coliforms in 100 mL of water } \\
\hline \multicolumn{1}{c}{ Mean } \\
\hline \multirow{2}{*}{ Month } & Nov & Jan & Apr & Jul & Nov & Jan & Apr & Jul \\
& 17 & 18 & 18 & 18 & 17 & 18 & 18 & 18 \\
\hline Sme & 9 & 10 & 08 & 10 & B & B & B & B \\
Bme & 20 & 40 & 30 & 90 & C & C & C & D \\
Bkw & 20 & 45 & 90 & 90 & C & C & D & D \\
Wkw & 40 & 65 & 30 & 30 & C & D & C & C \\
Smy & 10 & 35 & 50 & 65 & B & C & D & D \\
Wko & 45 & 40 & 100 & 40 & C & C & D & C \\
WHO & & & 0 & & & & A & \\
\hline
\end{tabular}

A: Excellent; B: Acceptable, Low risk; C: Unacceptable, High risk; D: Grossly polluted.

Table 9. One-way between groups ANOVA.

\begin{tabular}{|c|c|c|c|c|c|c|}
\hline & & Sum of Squares & $\mathrm{df}$ & Mean Square & $\mathrm{F}$ & Sig. \\
\hline & Between Groups & 14.688 & 3 & 4.896 & 3.489 & 0.035 \\
\hline \multirow[t]{3}{*}{ Temperature } & Within Groups & 28.062 & 20 & 1.403 & & \\
\hline & Total & 42.750 & 23 & & & \\
\hline & Between Groups & 1.939 & 3 & 0.646 & 1.384 & 0.277 \\
\hline \multirow[t]{3}{*}{$\mathrm{pH}$} & Within Groups & 9.345 & 20 & 0.467 & & \\
\hline & Total & 11.284 & 23 & & & \\
\hline & Between Groups & 287.408 & 3 & 95.803 & 0.188 & 0.903 \\
\hline \multirow[t]{3}{*}{$\mathrm{EC}$} & Within Groups & $10,186.790$ & 20 & 509.339 & & \\
\hline & Total & $10,474.198$ & 23 & & & \\
\hline & Between Groups & 88.561 & 3 & 29.520 & 0.142 & 0.933 \\
\hline \multirow[t]{3}{*}{ TDS } & Within Groups & 4149.558 & 20 & 207.478 & & \\
\hline & Total & 4238.120 & 23 & & & \\
\hline & Between Groups & 4.468 & 3 & 1.489 & 1.626 & 0.215 \\
\hline \multirow[t]{2}{*}{ Turbidity } & Within Groups & 18.320 & 20 & 0.916 & & \\
\hline & Total & 22.787 & 23 & & & \\
\hline
\end{tabular}


N. F. Biosengazeh et al.

\section{Continued}

\begin{tabular}{|c|c|c|c|c|c|c|}
\hline & Between Groups & 12.966 & 3 & 4.322 & 3.896 & 0.024 \\
\hline \multirow[t]{3}{*}{$\mathrm{Na}^{+}$} & Within Groups & 22.190 & 20 & 1.110 & & \\
\hline & Total & 35.157 & 23 & & & \\
\hline & Between Groups & 241.608 & 3 & 80.536 & 20.477 & 0.000 \\
\hline \multirow[t]{3}{*}{$\mathrm{K}^{+}$} & Within Groups & 78.661 & 20 & 3.933 & & \\
\hline & Total & 320.269 & 23 & & & \\
\hline & Between Groups & 4180.288 & 3 & 1393.429 & 10.697 & 0.000 \\
\hline \multirow[t]{3}{*}{$\mathrm{Ca}^{2+}$} & Within Groups & 2605.242 & 20 & 130.262 & & \\
\hline & Total & 6785.530 & 23 & & & \\
\hline & Between Groups & 325.583 & 3 & 108.528 & 10.419 & 0.000 \\
\hline \multirow[t]{3}{*}{$\mathrm{Mg}^{2+}$} & Within Groups & 208.334 & 20 & 10.417 & & \\
\hline & Total & 533.917 & 23 & & & \\
\hline & Between Groups & 0.314 & 3 & 0.105 & 1.579 & 0.226 \\
\hline \multirow[t]{3}{*}{$\mathrm{Cl}^{-}$} & Within Groups & 1.325 & 20 & 0.066 & & \\
\hline & Total & 1.639 & 23 & & & \\
\hline & Between Groups & 457.358 & 3 & 152.453 & 0.607 & 0.618 \\
\hline \multirow[t]{3}{*}{$\mathrm{HCO}_{3}^{-}$} & Within Groups & 5020.838 & 20 & 251.042 & & \\
\hline & Total & 5478.196 & 23 & & & \\
\hline & Between Groups & 16.070 & 3 & 5.357 & 3.240 & 0.044 \\
\hline \multirow[t]{3}{*}{$\mathrm{SO}_{4}^{2-}$} & Within Groups & 33.070 & 20 & 1.654 & & \\
\hline & Total & 49.140 & 23 & & & \\
\hline & Between Groups & 79.206 & 3 & 26.402 & 6.888 & 0.002 \\
\hline \multirow[t]{3}{*}{$\mathrm{NO}_{3}^{-}$} & Within Groups & 76.658 & 20 & 3.833 & & \\
\hline & Total & 155.864 & 23 & & & \\
\hline & Between Groups & 23.096 & 3 & 7.699 & 10.967 & 0.000 \\
\hline \multirow[t]{3}{*}{$\mathrm{NH}_{4}^{+}$} & Within Groups & 14.039 & 20 & 0.702 & & \\
\hline & Total & 37.135 & 23 & & & \\
\hline & Between Groups & 5.246 & 3 & 1.749 & 3.230 & 0.044 \\
\hline \multirow[t]{3}{*}{$\mathrm{PO}_{4}^{3-}$} & Within Groups & 10.829 & 20 & 0.541 & & \\
\hline & Total & 16.076 & 23 & & & \\
\hline & Between Groups & 0.006 & 3 & 0.002 & 0.149 & 0.929 \\
\hline \multirow[t]{3}{*}{$\mathrm{Fe}^{2+}$} & Within Groups & 0.254 & 20 & 0.013 & & \\
\hline & Total & 0.260 & 23 & & & \\
\hline & Between Groups & $15,803.125$ & 3 & 5267.708 & 0.529 & 0.667 \\
\hline \multirow[t]{3}{*}{ Enterobacteria } & Within Groups & $199,112.500$ & 20 & 9955.625 & & \\
\hline & Total & $214,915.625$ & 23 & & & \\
\hline & Between Groups & $24,236.458$ & 3 & 8078.819 & 2.274 & 0.111 \\
\hline \multirow[t]{2}{*}{ E. coli } & Within Groups & 7105.167 & 20 & 3552.708 & & \\
\hline & Total & $95,290.625$ & 23 & & & \\
\hline
\end{tabular}




\section{Continued}

\begin{tabular}{ccccccc}
\hline \multirow{2}{*}{ Streptococcus } & Between Groups & $15,411.458$ & 3 & 5137.153 & 1.746 & 0.190 \\
& Within Groups & $58,829.167$ & 20 & 2941.458 & & \\
& Total & $74,240.625$ & 23 & & & \\
\hline \multirow{3}{*}{ Salmonella } & Between Groups & 3861.458 & 3 & 1287.153 & 1.063 & 0.387 \\
& Within Groups & $24,212.500$ & 20 & 1210.625 & & \\
& Total & $28,073.958$ & 23 & & & \\
\hline \multirow{2}{*}{ Shigella } & Between Groups & 3841.667 & 3 & 1280.556 & \multirow{2}{*}{1.072} & 0.383 \\
& Within Groups & $23,891.667$ & 20 & 1194.583 & & \\
& Total & $27,733.333$ & 23 & & & \\
\hline
\end{tabular}

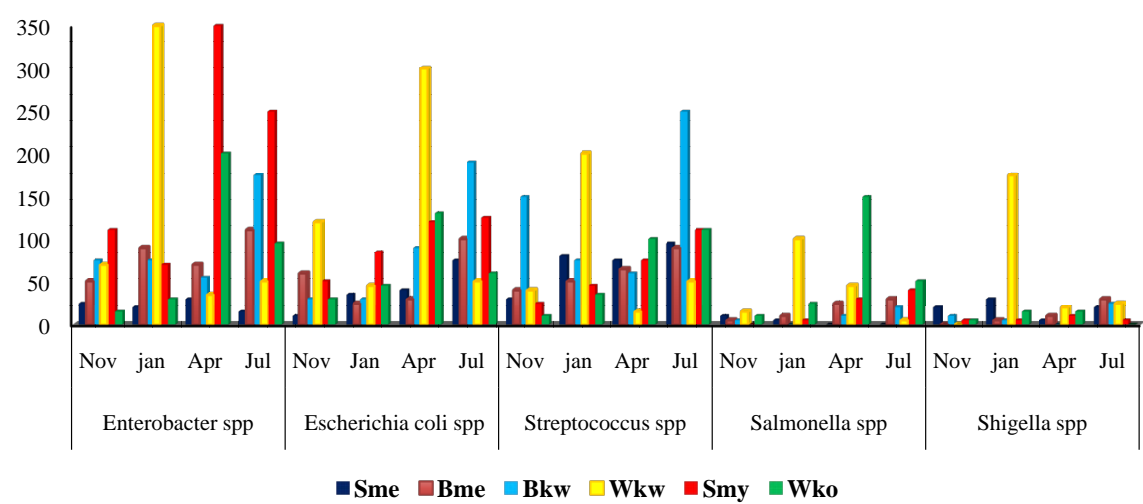

Figure 2. Specific bacteria isolated in the sampled waters between November 2017 and July 2018.

as the well was widely open to dust and leaves of trees found around. Organoleptic parameters of the water sources, except Wkw, conform to the WHO recommendation for safe drinking water and could be considered good for domestic purposes. However, there was no guarantee at this level as good domestic water must not only be clean, clear and odourless but also of good physicochemical and bacteriological quality.

Temperature values were between the minimum and maximum annual temperatures of $7.8^{\circ} \mathrm{C}$ and $33.6^{\circ} \mathrm{C}$ in this area (CVUC, 2019), also falling within the WHO guideline range of $15^{\circ} \mathrm{C}$ to $25^{\circ} \mathrm{C}$. One-way between groups ANOVA revealed a significant difference between temperature mean values $(\mathrm{F}(3.20)=3.489$, $p \leq 0.035$ ) (Table 9) and the Post-hoc comparisons using the Tukey HSD test further indicated that the difference was between mean temperatures in January and July. This was an increase, which could be as the result of seasonal changes, shade, air temperature, water depths and inflow of groundwater (WHO, 2011). However, the actual difference in mean values between groups was quite small as the effect size, calculated using eta squared, was 0.34 (Cohen, 1988). Studies carried out by Wotany et al. (2013) on the hydrogeochemical and anthropogenic influence on water quality in the Rio del Rey Basin, South Western Cameroon, Gulf of Guinea, revealed relatively high temperatures between 21 and $29^{\circ} \mathrm{C}$ 
which was also associated with seasonal influences. Though the sources had temperatures within the guideline range, it should be noted that high water temperature enhances the growth of microorganisms and may increase problems related to taste, odour, colour and corrosion (WHO, 2017). pH, Electrical Conductivity (EC), Total Dissolved Solids (TDS) and Turbidity did not vary significantly with seasons. Based on the results (Table 4), the water sources ranged from moderately acidic to weakly basic. Though some of the sources had $\mathrm{pH}$ values lower than the WHO established value of 6.5 , it had little or no direct effects on consumer's health as the $\mathrm{pH}$ of stomach fluid (gastric juice) is between 1.5 and 3.5. However, careful attention to $\mathrm{pH}$ control is necessary during water treatment to ensure satisfactory water clarification and disinfection (WHO, 2007). The insignificant change in $\mathrm{pH}$ suggests little effect of the rains on the water sources. Low EC and TDS in the water sources suggest low-mineralized and freshwaters (Wirmvem et al., 2013a). The strong positive correlation observed between EC and TDS $(r=0.994, p \leq 0.001)$ could be justified by the fact that EC arises from dissolved ionic matter. Mean $\mathrm{pH}, \mathrm{EC}$ and TDS obtained in January were similar to those reported by Wirmvem et al. (2013a) in ground waters in the studied area. All the waters had turbidity values far below the WHO guideline of $5 \mathrm{NTU}$, indicating the possible absence of hazardous chemicals and reduced microbial load (WHO, 2017).

\subsubsection{Chemical Parameters}

The presence of $\mathrm{Ca}^{2+}$ and $\mathrm{Mg}^{2+}$ in the studied water sources suggests the occurrence of limestone and chalk sendiments in the study area (WHO, 2011). Looking at their concentrations, calcium-based hardness was predominating due to the fact that magnesium is usually found at lower concentrations in groundwater (NRC, 1977). Seasonal changes also significantly influenced both ions concentrations $\left(\mathrm{F}(3.20)=10.697, p \leq 0.001 ; \mathrm{F}(2.20)=10.419, p \leq 0.001\right.$ for $\mathrm{Ca}^{2+}$ and $\mathrm{Mg}^{2+}$ respectively). This was a medium change (eta squared $=0.62$ and 0.61 ) which was further identified to be a decrease between November and January and an increase between January and July, April and July for $\mathrm{Ca}^{2+}$ and a decrease between November and January, an increase between January and July and between April and July for $\mathrm{Mg}^{2+}$. Based on WHO classification, the waters ranged from soft (hardness $<60 \mathrm{mg} / \mathrm{L}$ ) to moderately hard $(60 \mathrm{mg} / \mathrm{L} \leq$ hardness $\leq 120$ $\mathrm{mg} / \mathrm{l})$ (WHO, 2011). $\mathrm{Na}^{+}, \mathrm{K}^{+}$and $\mathrm{Cl}^{-}$concentrations were also very low compared to WHO standards of $200 \mathrm{mg} / \mathrm{L}$ for $\mathrm{Na}^{+}$and $\mathrm{K}^{+}$and $250 \mathrm{mg} / \mathrm{L}$ for $\mathrm{Cl}^{-}$respectively. Low sodium and chloride ions in the sampled waters could be as a result of low $\mathrm{NaCl}$ in the geological formations of the study area, as both ions are generally derived from the decomposition of rock salts like sodium and aluminium silicates (Belghiti et al., 2013; Mofor et al., 2017) and low $\mathrm{K}^{+}$may be due to its low geochemical mobility in the area (Wirmvem et al., 2013a). The positive correlation between $\mathrm{Na}^{+}$and $\mathrm{Cl}^{-}(\mathrm{r}=0.930, p \leq 0.007)$ suggest their common origin. Though they were in low concentrations, $\mathrm{Na}^{+}$and $\mathrm{K}^{+}$significantly fluctuated between seasons $(\mathrm{F}(3.20)=3.896, p \leq 0.024$ and $\mathrm{F}(3.20)=20.477, p \leq$ 0.001 respectively). Despite the statistical significance, the actual difference in 
the mean concentrations of $\mathrm{Na}^{+}$was quite small (eta squared $=0.34$ ) while that of $\mathrm{K}^{+}$was average (eta squared $\left.=0.75\right)$ (Cohen, 1988). Bicarbonate was the only ion responsible for water alkalinity as $\mathrm{CO}_{3}^{2-}$ and $\mathrm{OH}^{-}$were absent. Its concentrations were very low compared to the WHO guideline value of $1000 \mathrm{mg} / \mathrm{L}$ and did not significantly change with season. The presence of $\mathrm{HCO}_{3}^{-}$was necessary as it constitutes an important buffer system which helps in lowering the acidity of water (Njoyim et al., 2016c). $\mathrm{HCO}_{3}^{-}$originates from the partitioning of $\mathrm{CO}_{2}$ from the atmosphere and the weathering of carbonate minerals in rocks such as limestone and dolomite. Wirmwem et al. (2013a) also reported similar concentrations of $\mathrm{HCO}_{3}^{-}$in some bore holes and wells in the study area. Sulphate concentrations were insignificant regarding the WHO guideline value of $250 \mathrm{mg} / \mathrm{L}$ and did not show any significant difference between seasons. Low sulphates suggest low and the possible absence of minerals such as gypsum $\left(\mathrm{CaSO}_{4} \cdot 2 \mathrm{H}_{2} \mathrm{O}\right)$, pyrite $(\mathrm{FeS})$, barite $\left(\mathrm{BaSO}_{4}\right)$, and epsomite $\left(\mathrm{MgSO}_{4} \cdot 7 \mathrm{H}_{2} \mathrm{O}\right)$ in the study area. The presence of sulphate in drinking-water can cause noticeable taste, and very high levels might cause a laxative effect in unfamiliar consumers (WHO, 2004).

Nitrates found in the sampled waters in January probably came from nitrate producing bacteria (Nitrobacter), and the significant increase observed in its concentrations between January and July $(\mathrm{F}(3.20)=6.888, p \leq 0.002)$ suggest its infiltration from waste discharges and fertilisers into the water bodies. However, its concentrations were very low compared to the guideline value of $50 \mathrm{mg} / \mathrm{L}$. Interest is centred on nitrate mostly because its high levels in water has been reported to be responsible for the "blue baby" syndrome (methaemoglobinaemia) and typhoid effects (WHO, 2017). Low sulphates and nitrates were also reported in the study area (Wirmvem et al., 2013a) and elsewhere in Cameroon (Temgoua, 2011). $\mathrm{NH}_{4}^{+}$found in the water sources was surely from biological breakdown of domestic and agricultural wastes and its presence was thus an indicator of bacterial, sewage, and animal wastes contaminations (WHO, 2011; Aboudi et al., 2014). However, its low concentrations, far below the permissible limit of $30 \mathrm{mg} / \mathrm{L}$ prescribed by the WHO, showed no associated health risk. Phosphate concentrations were also very low in all the sampled waters without any significant differences with seasons. This could be due to its sorption on organic colloids. This result was in accordance with the observation of Wirmvem et al. (2013a). Iron was below detectable limits in most of the samples in January and had relatively low concentrations in November, April and July, the exception being Wkw (0.36 $\mathrm{mg} / \mathrm{L}$ ). Low iron could be due to the fact that the current water $\mathrm{pH}$ did not favour the solubility of its oxides and hydroxides leached from nearby soils. A contrary observation was made by Njoyim et al. (2016c) in ground waters in the Bangangte municipality of Cameroon. Though iron is vital for health, its low concentrations in the studied waters has no associated health risks as it can easily be gotten from other sources. Also, at levels above $0.3 \mathrm{mg} / \mathrm{L}$, iron oxides stain laundry and plumbing fixtures, gives noticeable taste to water, develops turbidity and colour and also promotes the growth of "iron bacteria" (WHO, 2011). 
The concentrations of major anionic and cationic constituents of the water samples were plotted on a Piper trilinear diagrams (Piper, 1953) to determine the water types. The plot of physicochemical data on the diamond shaped trilinear diagram (Figure 3 ) revealed that the analysed waters were calcium and magnesium bicarbonate type which are typical of shallow fresh ground waters.

Water quality index is one of the most effective tools to monitor surface, as well as ground, water pollution and can be used efficiently in the implementation of water quality upgrading programmes. As shown in Table 7, the computed WQI led to the grading of the waters between excellent (A) and unfit for drinking (Table 2). However, WQI may not convey sufficient information about the real quality situation of water since the concealing or overstressing of a single bad parameter value can give deceptive information about the water quality. Also, there are many other water quality parameters that are not included in the index and thus, other parameters need to be examined before a conclusion can be made about the overall water quality (Mofor et al., 2017).

\subsubsection{Bacteriological Parameters}

The presence of faecal coliforms in the sampled waters suggests recent contamination of the water sources by human or animal faeces and the possible presence of other pathogenic organisms (Njoyim et al., 2016b; Nanfack et al., 2014). This was confirmed through the identification of specific bacteria, namely Enterobacter spp, Escherichia coli spp, Streptococcus spp, Salmonella spp and Shigella $\operatorname{spp}$ (Figure 2), without any significant difference in their colony counts between seasons $(p>0.05)$. Based on the WHO guideline that recommends no bacteria of faecal origin in drinking water, all the sources were unfit for domestic uses such as drinking and bathing. According to Kuhn et al. (2001), domestic water with faecal coliform content above $100 \mathrm{CFU} / 100 \mathrm{~mL}$ will lead to serious health effects if used for drinking and cooking and will possibly cause infections if used for

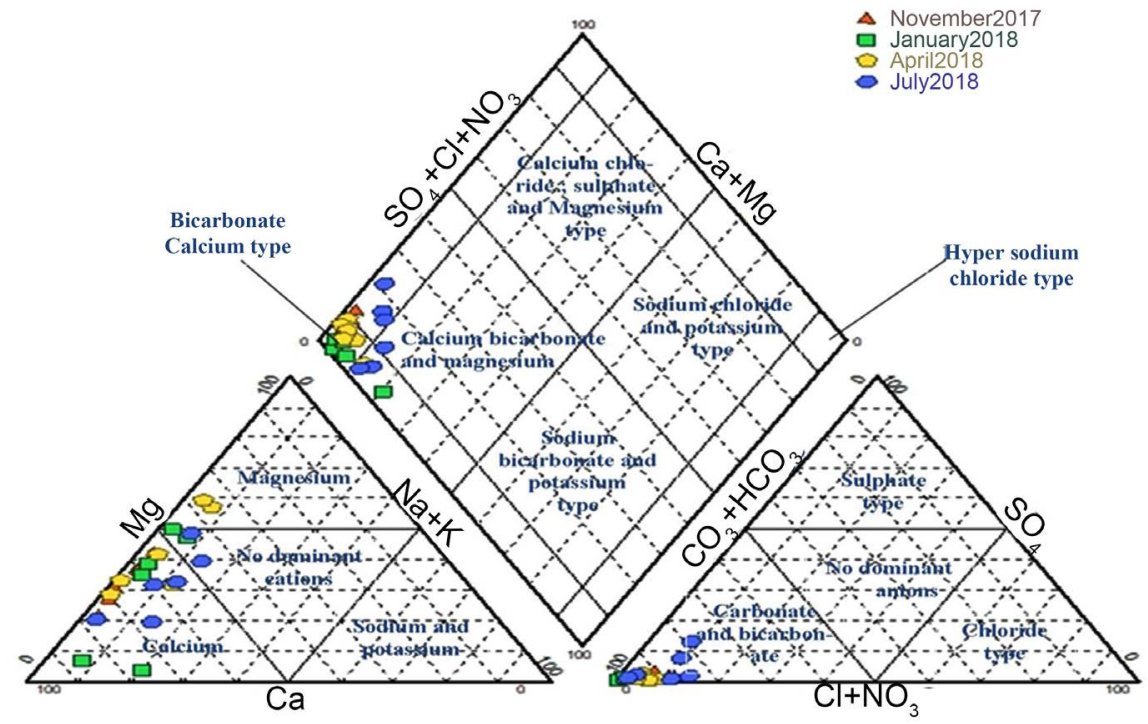

Figure 3. Piper's trilinear diagram showing ground water types. 
bathing and laundry. The presence of faecal coliforms and the abundance of specific pathogenic bacteria in most of the studied water sources can be associated to poor hygiene and sanitation (Nanfack et al., 2014; Mofor et al., 2017). One of the springs, Smy, was exposed to animals, dust and floods. Also, mostly children were found using unclean containers to collect water from this source which, according to Nanfack et al. (2014) had strong pathological influences on the water source. The low contamination of the spring of Mecheche (Sme) was surely because this spring has been constructed to prevent access to animals, dust and flood and any contamination may only originate from infiltration of microbes from underground. The wells were shallow and not properly protected. In addition, the enormous pollution of these water sources could be explained using other environmental related factors such as the low depth of the groundwater table and the behaviour of the population through open-air defecation. Poor bacteriological water quality has also been reported in this area (Wirmvem et al. 2013b; Njoyim et al. 2016a). The positive correlation between these bacteria: Enterrobacter-steptococcus $(\mathrm{r}=0.926)$, Salmonella spp-Shigella $\operatorname{spp}(\mathrm{r}=$ $0.969)$, Streptococcus spp-Salmonella spp $(\mathrm{r}=0.885)$ suggest their common origin. Based on the bacteriological parameters, all the water sources were unsuitable for human consumption, thus, exposing the local population to water borne diseases such as typhoid, diarrhoea and dysentery.

\section{Conclusion}

This study focused on the analysis of organoleptic, physicochemical and bacteriological properties of ground water, main source of domestic water, in Baba I in the North-West region of Cameroon following WHO guidelines. Results of organoleptic and physical parameters showed that most of the sources were of good organoleptic properties, had temperatures within the WHO acceptable limits with $\mathrm{pH}$ ranging from moderately acidic to weakly basic and had very low mineral content. Regarding the chemical aspect, all the analysed ions were found within the WHO guideline limits and the water sources ranged from soft to moderately hard with iron slightly above the WHO guideline value in Wkw in November and July respectively. Piper's trilinear diagrams also showed that the analysed waters were all calium and magnesium bicarbonate type, indicating shallow fresh ground waters. Small to average seasonal influences were observed in the variations of temperature and the concentrations of $\mathrm{Na}^{+}, \mathrm{K}^{+}, \mathrm{Ca}^{2+}, \mathrm{Mg}^{2+}, \mathrm{NO}_{3}^{-}$, and $\mathrm{NH}_{4}^{+}$. Looking at the bacteriological quality, Faecal coliforms and specific bacteria namely Escherichia coli, Enterobacteria, Streptococcus, Salmonella and Shigella spp were identified in all the sampled waters, suggesting recent contamination of the sources by human or animal faeces. The sources are unfit for domestic uses and thus, exposes the local population to water borne diseases such as typhoid, diarrhoea and dysentery. Therefore, home treatment methods such as chlorination, filtration, boiling and solar disinfection should be implemented prior to consumption. 


\section{Acknowledgements}

We thank the Babessi Council for the financial support provided to enable us carry out this research.

\section{Conflicts of Interest}

The authors declare that there are no conflicts of interest regarding the publication of this article.

\section{References}

Aboudi, A., Tabyaoui, H., El Hamichi, F., Benaabidate, L., \& Lahrach, A. (2014). Etude de la qualité physico-chimique et contamination métallique des eaux de surface du bassin versant de guigou, maroc. European Scientific Journal, 10, 84-94.

Ako Ako, A., Takem, G. E., \& Nkeng, G. E. (2010) Water Resources Management and Integrated Water Resources Management (IWRM) in Cameroon. Water Resources Management, 24, 871-888. https://doi.org/10.1007/s11269-009-9476-4

Belghiti, M. L., Chahlaoui, A., Bengoumi, D., \& El Moustaine, R. (2013). Etude de la qualite physico-chimique et Bactériologique des eaux souterraines de la nappe plio-quaternaire dans la région de meknès (Maroc). Larhyss Journal, 14, 21-36.

CAMAAY (2015). A Survey Report: Study on Water Management in Four Villages of Babessi Municipality. Bamenda: Cameroon Association of Active Youths.

Cohen, J. (1988). Statistical Power Analysis for the Behavioral Sciences (2nd ed.). Hillsdale, NJ: Lawrence Erlbaum Associates, New York.

CVUC (2019). Babessi Council. Yaoundé: Comunes et Villes Unies du Cameroun. http://www.cdr-cvuc.cm/index.php/fr

Institut National de la Statistique (INS) (2015). Rapport national sur les objectifs du millénaire pour le développement en 2015.

Katte V. Y., Fonteh, M. F., \& Guemuh, G. N. (2003). Domestic Water Quality in Urban Centres in Cameroon: A Case Study of Dschang in the West Province. African Water Journal Pilot Edition, 43-54.

Kuhn, A., Lesufi, W. N., \& Oelofse, A. P. M. (2001). Assessment Guide: Quality of Domestic Water Supply Volume One. Pretoria: Water Research Committee.

Mofor, N. A., Njoyim, E. B. T., \& Mvondo-Zé, A. D. (2017). Quality Assessment of Some Springs in the Awing Community, Northwest Cameroon, and Their Health Implications. Journal of Chemistry, 2017, Article ID: 3546163. https://doi.org/10.1155/2017/3546163

Nanfack, N. A. C., Fonteh, F. A., Payne, V. K., Katte, B., \& Fogoh, J. M. (2014). Eaux non conventionnelles: Un risque ou une solution aux problèmes d'eau pour les classes pauvres. Larhyss Journal, 17, 47-64.

Njoyim. E. B. T., Menga, T. R., Mofor, N. A., Nchofua, F. B., \& Njoyim, I. K. (2016c). Evaluation of Surface and Ground Water Quality in the Bangangte Municipality-West Cameroon. International Journal of Research and Review in Applied Sciences, 28, 53-64.

Njoyim, E. B. T., Mofor, N. A., Nib, M. L. F., \& Sunjo, J. (2016b). Physicochemical and Bacteriological Quality Assessment of the Bambui Community Drinking Water in the North West Region of Cameroon. African Journal of Environmental Science and Technology, 10, 181-191. 
Njoyim, E. B. T., Nchofua, F. B., Mofor, N. A., \& Djoko, Y. T. (2016a). Contrôle de la qualité des eaux domestiques dans le village Babessi au Nord-Ouest Cameroun. International Journal of Biological and Chemical Sciences, 10, 1382-1402. https://doi.org/10.4314/ijbcs.v10i3.37

NRC (1977). Drinking Water and Health. Washington DC: National Research Council, National Academy of Sciences.

Piper, A. M. (1953). Groundwater Notes 12: A Graphic Procedure in the Geochemical Interpretation of Water Analyses.

Rodier, J., Legube, B., Merlet, N. et al. (2009). L'analyse de l'eau, eaux naturelles, eaux résiduaires, eau de mer, chimie, physico-chimie, microbiologie, biologie, interprétation des résultats (9th éd). Paris: Dunod.

Satish Chandra, D., Asadi, S. S., \& Raju, M. V. S. (2017). Estimation of Water Quality Index by Weighted Arithmetic Water Quality Index Method: A Model Study. International Journal of Civil Engineering and Technology, 8, 1215-1222.

Temgoua, E. (2011). Chemical and Bacteriological Analysis of Drinking Water from Alternative Sources in the Dschang Municipality, Cameroon. Journal of Environmental Protection, 2, 620-628. https://doi.org/10.4236/jep.2011.25071

Tyagi, S., Singh, P., Sharma, B., \& Singh, R. (2014). Assessment of Water Quality for Drinking Purpose in District Pauri of Uttarakhand, India. Applied Ecology and Environmental Sciences, 2, 94-99. https://doi.org/10.12691/aees-2-4-2

WHO (2004). Sulfate in Drinking-Water Background Document for Development of WHO Guidelines for Drinking-Water Quality. Geneva: World Health Organization.

WHO (2007). pH in Drinking-Water. Revised Background Document for Development of WHO Guidelines for Drinking-Water Quality. Geneva: World Health Organization.

WHO (2009). Water and Public Health, WHO Seminar Pack for Drinking-Water Quality. Geneva: World Health Organization.

WHO (2011). Guidelines for Drinking-Water Quality (4th ed.). Geneva: World Health Organization.

WHO (2017). Guidelines for Drinking-Water Quality, Fourth Edition Incorporating the First Addendum. Geneva: World Health Organization.

WHO, \& UNICEF (2015). 2015 Update and MDG Assessment Report: Progress on Sanitation and Drinking Water. Geneva: World Health Organization and United Nations International Children Emergency Fund.

Wirmvem, M. J., Fantong, W. Y., Wotany, E. R., Takeshi, O., \& Ayonghe, S. N. (2013b). Sources of Bacteriological Contamination of Shallow Groundwater and Health Effects in Ndop Plain, Northwest Cameroon. Journal of Environmental Science and Water Resources, 2, 127-132.

Wirmvem, M. J., Takeshi, O., Fantong, W. Y., Ayonghe, S. N., Suila, J. Y., Asaah, A. N. E. et al. (2013a). Hydrochemistry of Shallow Groundwater and Surface Water in the Ndop Plain, North West Cameroon. African Journal of Environmental Science and Technology, 7, 518-530. https://doi.org/10.5897/AJEST2013.1456

Wotany, E. R., Ayonghe, S. N., Fantong, W. Y., Wirmvem, M. J., \& Takeshi, O. (2013). Hydrogeochemical and Anthropogenic Influence on the Quality of Water Sources in the Rio Del Rey Basin, South Western, Cameroon, Gulf of Guinea. African Journal of Environmental Science and Technology, 7, 1053-106. 